\title{
NESTING TREE PREFERENCE OF MALABAR PIED HORNBILL (ANTHRACOCEROS CORONATUS) IN PILLUR VALLEY, WESTERN GHATS, SOUTHERN INDIA
}

\author{
Prabakaran Girikaran ${ }^{1}$, Arockianathan Samson ${ }^{1, *}$, \\ Balasundaram Ramakrishnan ${ }^{1}$, Subramanian Ramasubramanian ${ }^{2}$ \\ ${ }^{1}$ Government Arts College, India \\ ${ }^{2}$ Tamil Nadu Forest Department, India \\ *e-mail: kingvulture1786@gmail.com
}

Received: 16.01.2019. Revised: 29.06.2019. Accepted: 16.07.2019.

\begin{abstract}
The Malabar Pied Hornbill (MPH) (Anthracoceros coronatus) is a Near Threatened taxon. This species is endemic to the low elevation moist forests of Western Ghats, a few locations in central India, Eastern Ghats and Sri Lanka. The present study, from November 2017 to March 2018, was aimed to understand the nesting tree preference of $A$. coronatus in the Pillur Valley, Western Ghats, Tamil Nadu, and Southern India. A total of five tree species were identified as nesting tree preference by the MPH in the Pillur Valley, Western Ghats. Four of these five tree species were identified as belonging to the hard wood category. The nesting tree Madhuca longifolia counted six nests $(\mathrm{n}=6)$ in five nesting trees $(\mathrm{n}=5)$. Overall seventeen nest site characters were calculated in order to understand the nesting tree preference of the MPH. The location of nests on the nesting trees shows that $55 \%$ of the nests were located on the primary branch. The location of the nest direction shows that most of the nests $(n=7)$ were located on the north east direction. The overall nest cavity length and width shows $31.38 \mathrm{~cm}$ and $18.06 \mathrm{~cm}$ respectively. The shape of the nest cavity shows that most of them, $70 \%$, have got an oval shape and $30 \%$ of the nests were having a round shape, irrespectively of the nesting trees. The potential nest tree and nest cavity availability in the 0.025 $\mathrm{km}^{2}$ study plots show that the overall availability of tree $\mathrm{GBH} \geq 250 \mathrm{~cm}$ was 9.43 per $0.01 \mathrm{~km}^{2}(23.57$ trees) and the availability of nest holes 4.57 per $0.01 \mathrm{~km}^{2}$ in 13 tree species.
\end{abstract}

Key words: cavity nester, Coimbatore, frugivorous, secondary cavity-nester, Tamil Nadu

\section{Introduction}

Hornbills are generally frugivorous, arboreal, and secondary cavity-nesters (Kemp, 1970; Leighton \& Leighton, 1983). They have always been considered important agents of seed dispersal in tropical forests (Leighton \& Leighton, 1983; Poonswad et al., 1983; Kemp, 1995; Kinnaird, 1998). Their vulnerability is mainly because of a loss of primary forest habitats due to various practices such as deforestation, habitat alteration, raising of plantations, agriculture, shifting cultivation and logging of old growth trees (Kemp \& Kemp, 1972; Leighton \& Leighton, 1983; Kannan \& James, 1997; Mudappa \& Kannan, 1997; Datta \& Rawat, 2004; Bachan, 2006). Historically, hornbills have also been subjected to hunting all over their range in Asia, contributing to their vulnerability (Bennett et al., 1997). Hornbills are a group of peculiar, largebodied birds found only in the Old World tropics that have been the focus of much conservation attention. Of the 54 species of hornbills known in the world (Kemp, 1995), nine species of horn- bills occur in India, four in south India: Great Hornbill (Buceros bicornis Linnaeus, 1758), Malabar Pied Hornbill (Anthracoceros coronatus (Boddaert, 1783)), Indian Grey Hornbill (Ocyceros birostris (Scopoli, 1786)), and Malabar Grey Hornbill (Ocyceros griseus (Latham, 1790)). The Malabar Pied Hornbill is a Near Threatened taxon (Collar et al., 1994; BirdLife International, 2016). This species is endemic to the low elevation moist forests of Western Ghats, a few locations in central India, Eastern Ghats and Sri Lanka (Ali \& Ripley, 1987). Datta \& Rawat (2004) lists this species among the four most threatened or rare hornbill species in India. Habitat loss due to shifting cultivation logging, and traditional hunting by tribes has been reported as important threats to hornbills in India in the northeast and the Western Ghats (Kannan \& James, 1997; Datta, 1998; Raman, 2001).

Past research on hornbills in India has addressed many aspects of the hornbill biology such as breeding, nest selection, and diet (Reddy, 1988; Kannan, 1994; Kannan \& James, 
1997; Mudappa \& Kannan, 1997; Raman, 2001; Balasubramanian et al., 2004; Datta \& Rawat 2004; Mudappa \& Raman, 2009). Less information is available on distribution and abundance patterns of hornbills, particularly in the face of large scale landscape transformations and continuing fragmentation and disturbance (Reddy et al., 1990; Datta, 1998; O'Brien et al., 1998; Raman \& Mudappa, 2003). A recent survey by Balasubramanian et al. (2004) recorded hornbill distribution at a number of sites in Kerala, Tamil Nadu, Karnataka, and Goa in the Western Ghats as well as in some parts of the Eastern Ghats. This survey found the Malabar Grey Hornbill to be the most frequently observed species and reported vegetation types in which each species occurred in the region.

The present study was aimed to understand the nesting tree preference of $A$. coronatus in the Pillur Valley, Western Ghats, Tamil Nadu, Southern India.

\section{Material and Methods}

\section{Study area}

The Western Ghats, a discontinuous chain of mountains located on the western side of peninsular India is approximately $1600 \mathrm{~km}$ long (North-South direction) extending from the
River Tapti valley in Gujarat to Kanyakumari in Tamil Nadu. The present study was conducted in the Pillur Valley, situated in the Coimbatore forest division of the Western Ghats in Tamil Nadu. The study area lies between $10.617^{\circ} \mathrm{N}$ and $11.517^{\circ} \mathrm{N}$ and $76.617^{\circ} \mathrm{E}$ and $77.083^{\circ} \mathrm{E}$ (Fig.). The altitude ranges from $0 \mathrm{~m}$ to $700 \mathrm{~m}$ and the area receives rain from the northeast monsoon. The annual average rainfall ranges from 1000 $\mathrm{mm}$ to $1400 \mathrm{~mm}$. Pillur is contiguous with the Kerala forests in the west and Coonoor slopes in the Nilgiri massif in the north. The forests in the area are unique and they exhibit a wide variety of floral diversity in different altitudinal and geographical zones. The major vegetation types of thePillur Valley are broadly classified into 1) dry deciduous scrub jungles; 2) riparian forests, and 3) the Phoenix savannah. The study site is rich in wildlife, including large mammalian herbivores such as elephant Elephas maximus and gaur Bos gaurus. Eighty-seven species of birds have been recorded in the riverine forests (Balasubramanian et al., 1998). Land along the River Bhavani is heavily settled with about ten settlements in the Pillur valley. "Irulars» are the predominant tribal inhabitants. They mainly depend on forests and forest products for their income, though some also practice agriculture.

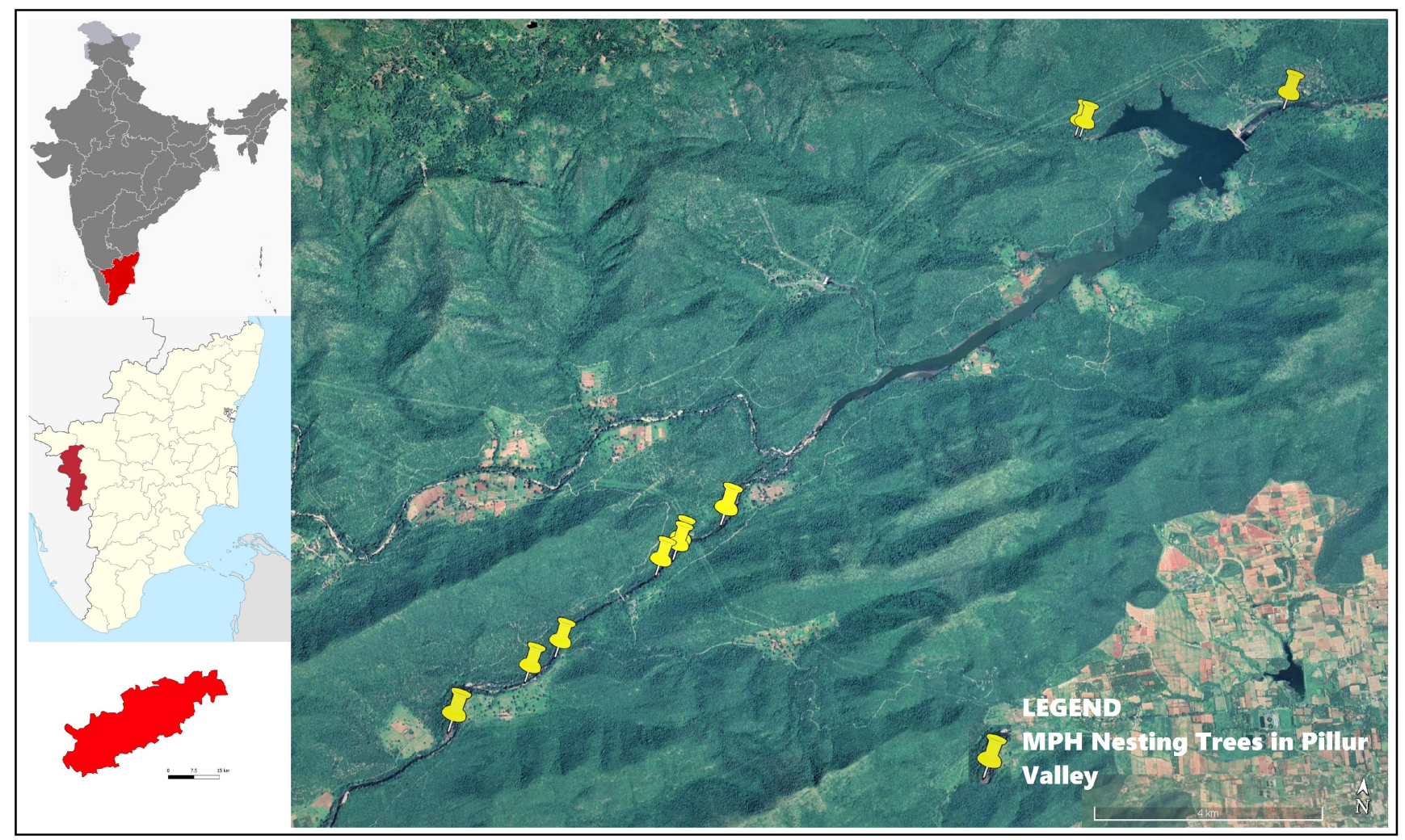

Fig. Pillur Valley with Malabar Pied Hornbill (Anthracoceros coronatus) nesting sites. 
Nesting tree survey

For surveying the cavity-nesting trees of the $\mathrm{MPH}$, the riparian habitats of the Pillur Valley were thoroughly searched on tall trees with binoculars. This survey was performed in the breeding season (November 2017 to April 2018) (Balasubramanian et al., 2004). Most of the nest trees were located through intensive searches in the area by inspecting potential nest trees with cavities. The presence of seedlings of hornbill food plants and middens (piles and regurgitated seeds and faecal matter) below trees with cavities also provide indirect evidence of the use as nest trees. The MPH nesting trees were marked with GPS coordinates and classified with identification. The quantification of nesting habitats followed methods suggested by James \& Shugart (1970) and subsequently by Kannan (1994) and Mudapa \& Kannan (1997). The vegetation and nest tree parameters were quantified in circular plots of $15 \mathrm{~m}\left(700 \mathrm{M}^{2}\right)$ with the nest tree in the centre. The nest tree species was noted. All the trees $(\mathrm{GBH}>25 \mathrm{~cm})$ were enumerated and the GBH (Girth at Brest Height) measured. The canopy cover was visually estimated. The elevation of the nesting tree, distance to the nearest road, and habitation were also noted. The nest tree parameters measured or estimated were nest tree species, tree height, basal area, diameter at breast height, number of primary branches and secondary branches (I: 5-10, II: 10-20, III: 20-30), canopy cover, canopy height, canopy width, number of used cavities and tree status, i.e. dead or alive.

Parameters such as tree density canopy cover were also quantified in similar sized plots located $100 \mathrm{~m}$ in a random direction from the nest tree. The nearest tree of GBH $>250 \mathrm{~cm}$ was chosen as the centre tree. And the same nest tree parameters were taken into account for comparison of random (non nest) plots with nest tree plots to determine parameters likely to affects the choice of nesting habitat by the MPH.

\section{Malabar Pied Hornbill nest cavity survey}

Once we identified the MPH nesting trees we monitored the usage of the nesting cavity by each MPH pair. We took into account the nest cavity variables for the consideration of nesting trees by the MPH according to Gómez (2014). These are 1) vertical and horizontal diameter of entrance hole, 2) shape of the entrance hole (round, oval or other), 3) aspect of the entrance hole (the direction of the entrance hole), 4) height of the cavity entrance above ground measured from the lower lip of the cavity to the base of the tree, 5) bird-excavated or natural decay cavity, 6) fresh / old cavity, 7) location of the cavity in trees (trunk / primary branch / secondary branch / tertiary branch), 8) tree DCH (tree diameter at cavity height) measured at the bottom of the cavity opening, 9) cavity to branch start distance, cavity to branch end distance.

\section{Potential nest tree species and availability}

The availability and density of potential nest tree species was assessed from ten 0.25 ha $(50 \mathrm{~m} \times$ $50 \mathrm{~m})$ vegetation plots $\left(0.025 \mathrm{~km}^{2}\right)$. In these plots, all trees were scanned for the presence of cavities or any possible signs of being used as a nest tree.

\section{Statistical treatment}

Mean (M) and standard error (SE) were calculated for each nest site variable. Pearson's correlation coefficient matrix was performed to understand the variable significances among the nesting trees. Paired samples t-tests were used to determine differences among the 13 parameters between nest $(\mathrm{n}=10)$ and non-nest $(\mathrm{n}=10)$ plots. The Principal Component Analysis was used to understand the nest site selection. Statistical analyses were performed with Graph Pad Prism 5 \& SPSS 17.0 statistical computer software.

\section{Results}

A total of five tree species, from five families, were identified as nesting tree preference by the MPH in the Pillur Valley, Western Ghats. Four of these five tree species were identified as belonging to the hardwood category, except Dysoxylum binectariferum (Roxb.) Hook. f. ex Bedd. Among the five nesting trees, Madhuca longifolia (J. Koenig ex L.) J.F. Macbr. counted the highest number of nests $(n=6)$, found in five trees $(n=5)$, followed by Spondias pinnata (L. f.) Kurz $(\mathrm{n}=2)$. Terminalia bellirica (Gaertn.) Roxb., Syzygium cumini (L.) Skeels and Dysoxylum binectariferum (Roxb.) Hook. f. ex Bedd. have been recorded each one time. A total of 17 variables were distinguished from the nesting trees for analysing the nesting preference of the MPH in the study area (Table 1).

Fifteen variables of nest trees at the nest site and fifteen variables of the centre tree at non-nest sites were measured and are given below (Table 2). Nest trees differed significantly in terms of size from centre trees of non-nest plots. The height of the tree, branch end, branch start and branch end distances, height of the first branch, canopy length, nest holes availability and distance to human habi- 
tation were all significantly larger in nest trees than in non-nest centre trees (Table 2). But there was no significant difference in basal area, girt at breast height, branch start, primary branches, canopy width, canopy cover, elevation and distances to road between nest plot and centre trees of non-nest plots. However, there was a significant difference in large tree density $(\mathrm{GBH} \geq 276-325$ and $325 \mathrm{~cm})$ between the nest and non-nest plots (Table 2).

The Principal component analysis (PCA) was carried out using the nest site characteristics data from all the observed nests $(\mathrm{n}=10)$. Table 3 shows the Pearson's correlation matrix between the 17 variables.

Table 1. Nesting tree characteristics preferred by Malabar Pied Hornbill for nest construction in Pillur Valley, Western Ghats, India

\begin{tabular}{|c|c|c|c|c|c|c|}
\hline Nest site variables & $\begin{array}{c}\text { Madhuca longifolia } \\
(\mathrm{n}=5)\end{array}$ & \begin{tabular}{|c|}
$\begin{array}{c}\text { Spondias pinnata } \\
(\mathrm{n}=2)\end{array}$ \\
\end{tabular} & $\begin{array}{c}\text { Dysoxylum } \\
\text { binectariferum }(\mathrm{n}=1)\end{array}$ & $\begin{array}{c}\text { Syzygium } \\
\text { cumini }(\mathrm{n}=1)\end{array}$ & \begin{tabular}{|c|} 
Terminalia \\
bellirica $(\mathrm{n}=1)$ \\
\end{tabular} & $\begin{array}{l}\text { Average } \\
(\mathrm{n}=10)\end{array}$ \\
\hline Height $(\mathrm{m})$ & 26.4 & 26 & 32 & 27 & 28 & $27.88 \pm 1.25$ \\
\hline Basal area $(\mathrm{cm})$ & 487.6 & 619 & 389 & 413 & 782 & $538.12 \pm 72.95$ \\
\hline $\mathrm{DBH}(\mathrm{cm})$ & 348.4 & 479 & 357 & 265 & 592 & $408.28 \pm 57.24$ \\
\hline Branch start (m) & 12.6 & 9 & 18 & 11 & 14 & $12.92 \pm 1.51$ \\
\hline Branch end $(\mathrm{m})$ & 25.2 & 25 & 31 & 26 & 27 & $26.84 \pm 1.09$ \\
\hline Primary branch $(\mathrm{m})$ & 7.2 & 6 & 3 & 3 & 9 & $5.64 \pm 1.17$ \\
\hline Secondary branch $(\mathrm{m})$ & II & III & I & I & II & II \\
\hline Branch start to branch end distance $(\mathrm{m})$ & 12.8 & 16 & 13 & 15 & 13 & $13.96 \pm 0.64$ \\
\hline Canopy cover & $32 \%$ & $65 \%$ & $50 \%$ & $20 \%$ & $60 \%$ & $45 \% \pm 8.49 \%$ \\
\hline Canopy length (m) & 11.8 & 16.5 & 13 & 20 & 13 & $14.86 \pm 1.50$ \\
\hline Canopy width (m) & 20 & 20 & 20 & 17 & 26 & $20.6 \pm 1.46$ \\
\hline Distance to human habitation $(\mathrm{km})$ & 4.51 & 4.04 & 4.65 & 4.64 & 5.71 & $4.38 \pm 0.17$ \\
\hline Distance to road $(\mathrm{km})$ & 0.38 & 0.13 & 0.09 & 0.06 & 0.26 & $0.23 \pm 0.06$ \\
\hline Elevation $(\mathrm{m})$ & 447.8 & 449 & 447 & 449 & 371 & $438.12 \pm 9.59$ \\
\hline Ground to nest height (m) & 14.8 & 14 & 16 & 13 & 17 & $14.96 \pm 0.70$ \\
\hline Branch start to nest height (m) & 3.4 & 5 & 5 & 5 & 3 & $4.28 \pm 0.44$ \\
\hline Branch end to nest height (m) & 10.8 & 14 & 11 & 19 & 10 & $12.96 \pm 1.65$ \\
\hline Tree diameter at cavity height (m) & 178.6 & 311 & 125 & 214 & 347 & $235.12 \pm 41.25$ \\
\hline
\end{tabular}

Table 2. Characteristics of nest-site and non-nest site plots of MPH in Pillur Valley, Western Ghats, Southern India

\begin{tabular}{|c|c|c|c|c|}
\hline Variables & Nest plot $(\mathrm{n}=10)$ & Non-nest plot $(\mathrm{n}=10)$ & $t$ & $\mathrm{p}<0.05$ \\
\hline Nest / centre tree height $(\mathrm{m})$ & $27.88 \pm 1.25$ & $25 \pm 0.44$ & 2.74 & $0.02 *$ \\
\hline Nest / centre tree basal area $(\mathrm{cm})$ & $538.12 \pm 72.95$ & $490 \pm 6.89$ & 0.68 & 0.51 \\
\hline Nest / centre tree girth at breast height $(\mathrm{cm})$ & $408.28 \pm 57.24$ & $398.1 \pm 6.25$ & 0.85 & 0.42 \\
\hline Nest / centre tree branch start $(\mathrm{m})$ & $12.92 \pm 1.51$ & $11.5 \pm 0.30$ & 1.49 & 0.17 \\
\hline Nest / centre tree branch end $(\mathrm{m})$ & $26.84 \pm 1.09$ & $23.6 \pm 0.45$ & 3.05 & $0.01 *$ \\
\hline Nest / centre tree branch start and branch end distance $(\mathrm{m})$ & $13.96 \pm 0.64$ & $10.8 \pm 0.77$ & 3.21 & $0.01 *$ \\
\hline Nest / centre tree primary branches & $5.64 \pm 1.17$ & $5.6 \pm 0.45$ & 1.18 & 0.27 \\
\hline Nest / centre tree canopy length (m) & $14.79 \pm 0.65$ & $21.2 \pm 1.07$ & 2.49 & $0.03 *$ \\
\hline Nest / centre tree canopy width $(\mathrm{m})$ & $13.5 \pm 0.88$ & $20.9 \pm 0.98$ & 0.27 & 0.79 \\
\hline Nest / centre tree canopy cover $(\%)$ & $45 \pm 8.49$ & $40 \pm 2.10$ & 0.09 & 0.93 \\
\hline Nest / centre tree nest holes availability & $2.4 \pm 0.42$ & $0.5 \pm 0.16$ & 3.767 & $0.00 *$ \\
\hline Nest / centre tree distance to human habitation $(\mathrm{km})$ & $4.38 \pm 0.17$ & $4.93 \pm 0.18$ & 6.72 & $0.00 *$ \\
\hline Nest / centre tree distance to road $(\mathrm{km})$ & $0.23 \pm 0.06$ & $0.32 \pm 0.09$ & 0.78 & 0.46 \\
\hline Nest / centre tree elevation $(\mathrm{m})$ & $438.12 \pm 9.59$ & $441.12 \pm 7.20$ & 1.17 & 0.28 \\
\hline \multicolumn{5}{|c|}{ Tree density / $0.01 \mathrm{~km}^{2}$} \\
\hline i) Trees of $\mathrm{GBH} \geq 25 \mathrm{~cm}$ & $18.67 \pm 1.12$ & $37 \pm 4.18$ & 6.118 & 0.124 \\
\hline ii) Trees of GBH $\geq 26-75 \mathrm{~cm}$ & $4 \pm 0.87$ & $6 \pm 2.02$ & -1.794 & 0.187 \\
\hline iii) Trees of GBH $\geq 76-125 \mathrm{~cm}$ & $2 \pm 0.58$ & $5.2 \pm 1.53$ & -3.187 & 0.357 \\
\hline iv) Trees of GBH $\geq 126-175 \mathrm{~cm}$ & $1.2 \pm 0.37$ & $5.4 \pm 1.21$ & -3.121 & 0.112 \\
\hline v) Trees of GBH $\geq 176-225 \mathrm{~cm}$ & $2 \pm 0.37$ & $6.3 \pm 1.83$ & 2.657 & 0.132 \\
\hline vi) Trees of GBH $\geq 226-275 \mathrm{~cm}$ & $1.45 \pm 0.29$ & $3.4 \pm 1.59$ & -1.759 & 0.149 \\
\hline vii) Trees of GBH $\geq 276-325 \mathrm{~cm}$ & $2.5 \pm 0.35$ & $2.4 \pm 0.60$ & 1.876 & $0.007 *$ \\
\hline viii) Trees of GBH $\geq 325 \mathrm{~cm}$ & $1.87 \pm 0.45$ & $1.6 \pm 0.81$ & 1.177 & $0.005^{*}$ \\
\hline
\end{tabular}

Note: *Parameters that was significantly different between nest and non-nest plot. 
Table 3. Pearson's correlation coefficient matrix between nesting tree variables, by Malabar Pied Hornbill in Pillur Valley Western Ghats, India

\begin{tabular}{|c|c|c|c|c|c|c|c|c|c|c|c|c|c|c|c|c|c|}
\hline Variables & NTH & BA & GBH & BS & $\mathrm{BE}$ & PB & BSBED & $\mathrm{CC}$ & $\mathrm{CL}$ & $\mathrm{CW}$ & GNH & BSNH & BENH & TGCH & DHH & DR & ELEV \\
\hline NTH & 1.00 & & & & & & & & & & & & & & & & \\
\hline BA & -0.25 & 1.00 & & & & & & & & & & & & & & & \\
\hline GBH & 0.00 & $0.95^{*}$ & 1.00 & & & & & & & & & & & & & & \\
\hline BS & $0.82 *$ & -0.25 & -0.03 & 1.00 & & & & & & & & & & & & & \\
\hline $\mathrm{BE}$ & $0.97^{*}$ & -0.34 & -0.08 & $0.92 *$ & 1.00 & & & & & & & & & & & & \\
\hline PB & $-0.47 * *$ & $0.87^{*}$ & $0.79 *$ & -0.19 & -0.44 & 1.00 & & & & & & & & & & & \\
\hline BSBED & -0.31 & 0.01 & -0.08 & -0.79 & $-0.48 * *$ & -0.29 & 1.00 & & & & & & & & & & \\
\hline $\mathrm{CC}$ & 0.24 & $0.67^{*}$ & $0.85^{*}$ & 0.06 & 0.15 & $0.45^{*}$ & 0.10 & 1.00 & & & & & & & & & \\
\hline CL & -0.14 & -0.24 & -0.40 & -0.59 & -0.31 & -0.54 & $0.81^{*}$ & -0.36 & 1.00 & & & & & & & & \\
\hline $\mathrm{CW}$ & 0.12 & $0.86^{*}$ & $0.91 *$ & 0.27 & 0.11 & $0.81^{*}$ & $-0.47 * *$ & $0.66^{*}$ & $-0.60 * *$ & 1.00 & & & & & & & \\
\hline GNH & $0.48^{*}$ & $0.50^{*}$ & $0.67 *$ & $0.70 *$ & $0.54 *$ & $0.52 *$ & $-0.74 * *$ & $0.56^{*}$ & $-0.79 * *$ & $0.87 *$ & 1.00 & & & & & & \\
\hline BSNH & 0.33 & $-0.63 * *$ & $-0.53 * *$ & -0.12 & 0.24 & $-0.88 * *$ & $0.65^{*}$ & -0.10 & $0.64 *$ & $-0.75 * *$ & $-0.61 * *$ & 1.00 & & & & & \\
\hline BENH & -0.21 & -0.41 & $-0.58 * *$ & -0.56 & -0.33 & $-0.61 * *$ & $0.73 *$ & $-0.56 * *$ & $0.97^{*}$ & $-0.74 * *$ & $-0.88 * *$ & $0.64 *$ & 1.00 & & & & \\
\hline TGCH & -0.37 & $0.92 *$ & $0.80^{*}$ & -0.54 & -0.52 & $0.68^{*}$ & 0.37 & $0.56^{*}$ & 0.15 & $0.61^{*}$ & 0.16 & -0.36 & -0.03 & 1.00 & & & \\
\hline DHH & 0.27 & $0.54^{*}$ & $0.52^{*}$ & 0.43 & 0.25 & $0.49^{*}$ & $-0.59^{* *}$ & 0.12 & -0.31 & $0.77^{*}$ & $0.72 *$ & $-0.69^{* *}$ & -0.39 & 0.36 & 1.00 & & \\
\hline DR & $-0.54 * *$ & 0.39 & 0.31 & 0.00 & -0.38 & $0.79 *$ & $-0.58 * *$ & 0.01 & $-0.72 * *$ & $0.47 *$ & 0.38 & $-0.88 * *$ & $-0.64 * *$ & 0.13 & 0.27 & 1.00 & \\
\hline ELEV & -0.12 & $-0.83^{* *}$ & $-0.81 * *$ & -0.19 & -0.06 & $-0.70 * *$ & 0.37 & $-0.45 * *$ & 0.31 & $-0.92 * *$ & $-0.73 * *$ & $0.71 *$ & 0.46 & $-0.67 * *$ & $-0.91 * *$ & -0.31 & 1.00 \\
\hline
\end{tabular}

Note: * - positive correlation in $\mathrm{p}<0.05$ between the variables; ** - negative correlation $\mathrm{p}<0.05$ between the variables. Parameters: NTH - nest tree height, BA - basal area, GBH - girth brest height, BS - branch start, BE - branch end, PB - primary branch, BSBED - branch start and branch end distance, $\mathrm{CC}$ - canopy cover, CL - canopy length, CW - canopy width, GNH - ground to nest height, BSNH - branch start nest height, BENH - branch end nest height, TGCH - tree girth at cavity height, DHH - distance to human habitation, DR - distance to road, ELEV - elevation.

The Principal Component Analysis (PCA) extracted four principal components that elucidated $100 \%$ variability (Table 4). The first component (PC1) explained $49.71 \%$ variability which gives details of nine nest tree variables: tree height, basal area, girth at breast height $(\mathrm{GBH})$, branch start and branch end distance, canopy cover, canopy width, ground to nest height, tree diameter at cavity height, distance to human habitation and distance to road in the plot and those were positively correlated with the first component. High values on the first component correspond to the large girth of nest trees, tallness of nest trees, branch start and branch end distance and ground to nest height, tree diameter to cavity height. Thus, the first component indicated (with increasing values) that the size of the nest tree and tallness will also increase. The first component was also positively correlated with the distance to road variable, which indicates (with increasing values) a larger distance to a road and habitation. The second component (PC2) explained $27.29 \%$ variability by four nest tree variables: basal area, branch start and branch end distance, primary branch, tree diameter at cavity height (Table 4). High values on the second component correspond to the basal area, branch start and branch end distance, primary branch, tree diameter at cavity height. Thus, the second component also represents (with increasing values) the size of the nest tree and basal area and branch structure of the tree. The third component (PC3) explained 15.09\% of the total variance and was related to nest tree height, tree density and distance to the road side. The fourth component (PC4) explained $7.92 \%$ of the total variance and was related to the canopy cover of nesting trees (Table 4).

Cavity orientation of nest trees did not differ significantly from random (Rayleigh test, $\mathrm{r}=$ $0.4685, \mathrm{p}<0.05, \mathrm{n}=11)$. The location of the nest hole in the trees showed that $55 \%$ of the nests were located in the primary branch followed by $27 \%$ of nests located on the secondary branches and $18 \%$ of the nests positioned in the main trunk of the trees. The nest direction in the trees showed that most of the nests $(n=7)$ were located on the north east direction, followed by south west $(n=2)$ and north west $(n=1)$. It should be noted that none of the nests was found in the southeast direction. The overall nest cavity length and width amounts 31.38 $\mathrm{cm}$ and $18.06 \mathrm{~cm}$ respectively. But it differed between tree species. The length in Spondias pinnata was $37.5 \mathrm{~cm}$, and the width in Dysoxylum binectariferum $21 \mathrm{~cm}$. The study of the nest cavity shape showed that most of the nests $(70 \%)$ had anoval shape and $30 \%$ of the observed nests had a round shape, irrespectively of the nesting tree species. 
Table 4. Summary statistics of Principal Component Analysis

\begin{tabular}{|l|c|c|c|c|c|c|c|c|c|}
\hline \multirow{2}{*}{ Variables } & \multirow{2}{*}{ Communality } & \multicolumn{2}{c|}{ PC1 } & \multicolumn{2}{c|}{ PC2 } & \multicolumn{2}{c|}{ PC3 } & \multicolumn{2}{c|}{ PC4 } \\
\cline { 3 - 9 } & & $\mathrm{r}$ & $\mathrm{c}$ & $\mathrm{r}$ & $\mathrm{c}$ & $\mathrm{r}$ & $\mathrm{c}$ & $\mathrm{r}$ & $\mathrm{c}$ \\
\hline Height & 0.97 & $0.45^{*}$ & 0.01 & -0.83 & -0.18 & $0.56^{*}$ & 0.22 & -0.04 & -0.03 \\
\hline Basal area & 0.98 & $0.80^{*}$ & 0.09 & $0.54^{*}$ & 0.12 & 0.27 & 0.10 & -0.01 & -0.01 \\
\hline GBH & 1.00 & $0.85^{*}$ & 0.10 & 0.31 & 0.07 & 0.39 & 0.15 & 0.17 & 0.13 \\
\hline Branch start & 0.98 & 0.31 & 0.04 & -0.95 & -0.20 & 0.03 & 0.01 & -0.07 & -0.05 \\
\hline Branch end & 0.99 & 0.08 & 0.01 & -0.93 & -0.20 & 0.35 & 0.14 & 0.01 & 0.00 \\
\hline Branch start and branch end distance & 1.00 & $0.85^{*}$ & 0.10 & $0.46^{*}$ & 0.10 & -0.23 & -0.09 & 0.06 & 0.05 \\
\hline Primary branch & 0.97 & -0.58 & -0.07 & $0.64^{*}$ & 0.14 & $0.46^{*}$ & 0.18 & 0.18 & 0.13 \\
\hline Canopy cover & 0.86 & $0.58^{*}$ & 0.07 & 0.11 & 0.02 & $0.57^{*}$ & 0.22 & $0.57^{*}$ & 0.42 \\
\hline Canopy length & 0.87 & -0.72 & -0.09 & 0.42 & 0.09 & 0.40 & 0.15 & -0.38 & -0.28 \\
\hline Canopy width & 0.96 & $0.98^{*}$ & 0.12 & 0.04 & 0.01 & 0.19 & 0.07 & -0.05 & -0.03 \\
\hline Ground to nest height & 0.99 & $0.88^{*}$ & 0.10 & -0.45 & -0.10 & 0.13 & 0.05 & 0.04 & 0.03 \\
\hline Branch start to nest height & 0.95 & -0.84 & -0.10 & -0.15 & -0.03 & $0.47^{*}$ & 0.18 & 0.23 & 0.17 \\
\hline Branch end to nest height & 0.89 & -0.82 & -0.10 & 0.36 & 0.08 & 0.19 & 0.08 & -0.40 & -0.30 \\
\hline Tree diameter at cavity height & 0.96 & $0.50^{*}$ & 0.06 & $0.76^{*}$ & 0.16 & 0.41 & 0.16 & -0.09 & -0.07 \\
\hline Distance to human habitation & 0.99 & $0.74^{*}$ & 0.09 & -0.17 & -0.04 & 0.12 & 0.05 & -0.64 & -0.47 \\
\hline Distance to road & 0.97 & $0.62^{*}$ & 0.07 & 0.17 & 0.04 & -0.75 & -0.30 & 0.11 & 0.08 \\
\hline Elevation & 0.97 & -0.87 & -0.10 & -0.12 & -0.03 & -0.27 & -0.11 & 0.40 & 0.30 \\
\hline Eigen value & \multicolumn{2}{|c|}{8.46} & & 4.64 & & 2.56 & & 1.35 \\
\hline \% variance explained & \multicolumn{2}{|c|}{49.75} & 27.29 & & 15.04 & \\
\hline
\end{tabular}

Note: *correlation significant at $\mathrm{p}<0.05 ; \mathrm{r}-$ Pearson's correlation coefficient, $\mathrm{c}$ - factor score coefficient.

A total of 13 potential nest tree species of the MPH occurring at the study area was identified. These trees generally attain a large size (Table 5). Of these, only five species, Madhuca longifolia, Terminalia bellirica, Dysoxylum binectariferum, Spondias pinnata, and Syzygium cumini were used for nesting by the MPH. Four species are hardwood trees but tends to rot easily. All of these trees were emergent, large girth trees and are relatively more common than other species. In fact, Madhuca longifolia was the most common tree species. The overall occurrence of Madhuca longifolia was 2.69 trees per $0.01 \mathrm{~km}^{2}$ for trees of $\mathrm{GBH} \geq 250$ $\mathrm{cm}$, recorded in the ten $2500 \mathrm{~m}^{2}$ plots during the study period (Table 5). The density of large tree $(\mathrm{GBH} \geq 250 \mathrm{~cm})$ species Pongamia pinnata (L.) Pierre was 4 per $0.01 \mathrm{~km}^{2}$ on the basis of studying the ten $2500 \mathrm{~m}^{2}$ plots. Terminalia bellirica, Terminalia crenulata Roth., Dysoxylum binectariferum, Ailanthus excelsa Roxb., and Albizia lebbeck (L.) Benth were 1.6 trees per $0.01 \mathrm{~km}^{2}$ recorded in the ten $2500 \mathrm{~m}^{2}$ plots (Table 5). Apart from wood type and tree size, the overall availability of the species was an important factor in the nest tree selection by MPH. In the study plots, the overall availability of trees of GBH $\geq 250 \mathrm{~cm}$ was 9.43 per $0.01 \mathrm{~km}^{2}$ (23.57 trees) and the availability of nest holes was 4.57 per $0.01 \mathrm{~km}^{2}$, including 13 species (Table 5).

Table 5. Potential nest tree species, tree characteristics and availability of MPH in Pillur Valley, Western Ghats, Southern India

\begin{tabular}{|c|l|c|c|c|c|}
\hline No & \multicolumn{1}{|c|}{ Tree species } & Height (m) & $\begin{array}{l}\text { Wood } \\
\text { Type }\end{array}$ & $\begin{array}{c}\text { Overall tree density } / \\
0.01 \mathrm{~km}^{2}\end{array}$ & $\begin{array}{c}\text { Tree density } / 0.01 \mathrm{~km}^{2} \\
(\mathrm{GBH} \geq 250 \mathrm{~cm})\end{array}$ \\
\hline 1 & Manilkara hexandra (Roxb.) Dubard & $16-24$ & HW & 2 & 0.4 \\
\hline 2 & Terminalia bellirica (Gaertn.) Roxb. & $14-27$ & HW & 1.6 & 0.8 \\
\hline 3 & Dalbergia sissoo DC. & $15-23$ & HW & 1.2 & 0.4 \\
\hline 4 & Madhuca longifolia (J.Koenig ex L.) J.F.Macbr & $19-28$ & HW & 2.69 & 2.69 \\
\hline 5 & Terminalia crenulata Roth. & $12-22$ & HW & 1.6 & 0.8 \\
\hline 6 & Dysoxylum binectariferum (Roxb.) Hook. f. ex Bedd. & $17-34$. & HW & 1.6 & 0.8 \\
\hline 7 & Spondias pinnata (L.f.) Kurz. & $12-22$. & HW & 2 & 0.4 \\
\hline 8 & Syzygium cumini (L.) Skeels & $14-25$ & HW & 1.2 & 0.4 \\
\hline 9 & Pongamia pinnata (L.) Pierre & $7-18$. & HW & 4 & 0.8 \\
\hline 10 & Ailanthus excelsa Roxb. & $10-19$. & SW & 1.6 & 0.4 \\
\hline 11 & Alseodaphne semecarpifolia Nees. & $9-18$. & HW & 1.2 & 0.4 \\
\hline 12 & Diospyros peregrina (Gaertn.) Gurke & $8-14$. & HW & 0.8 & 0.4 \\
\hline 13 & Albizia lebbeck (L.) Benth & $11-22$. & HW & 1.6 & 0.8 \\
\hline
\end{tabular}

Note: HW - hardwood, SW - softwood. 


\section{Discussion}

Cavities are an important source in forests for numerous birds and mammals which use them for nesting, roosting, and escaping from predators. To a certain scope, the preference of cavities may also depend on the faunal community, particularly in provisions of keep away from interspecific antagonism for nest sites and food (Kalina, 1988; Li \& Martin, 1991; Conway \& Martin, 1993), predation (Kemp, 1976; Cody, 1985; Martin, 1988), and the occurrence of sufficient foraging habitat (Conner, 1976). The nesting trees of the MPH were observed at a lower altitude $(<450 \mathrm{~m})$ in riverine habitats of the Pillur valley. Reddy et al. (1990) and Balasubramanian et al. (2004) stated that the importance of riverine habitats for the conservation of the MPH has been clearly underlined over the years. Mudappa \& Raman (2009) recorded the MPH most recurrently at lower altitude $(<600 \mathrm{~m})$ in moist deciduous and riverine areas on the Western Ghats. Balasubramanian et al. (2004) observed that the distribution and variation in a number of the MPH in the Athikadavu valley region were strongly governed by the availability of fruit trees, their fruiting season and the availability of suitable roosting habitat.

For the MPH, a total of five nesting trees were identified in the Pillur Valley, namely Madhuca longifolia, Spondias pinnata, Terminalia bellirica, Syzygium cumini, and Dysoxylum binectariferum. Balasubramanian et al. (2004) reported that Madhuca longifolia and Terminalia arjuna (Roxb. ex DC.) Wight \& Arn. were utilised as nesting trees by the MPH in the Athikadavu valley in the Western Ghats. Bachan et al. (2011) recorded that MPH nests were observed on Tetrameles nudiflora $\mathrm{R}$. Br. and one on Terminalia bellirica in the Anamalai Hills of Southern Western Ghats, India. Among the five nesting trees in the Pillur Valley, Madhuca longifolia was the highest utilised species by the MPH. The significance of single preference of nesting tree species (Tetrameles nudiflora, Palaquium amboinense Burck, Syzygium spp., and Pangium edule Reinw.) was reported in other studies in and outside India (Kinnaird \& O'Brien, 1993; Mardiastuti et al., 1996; Marsden \& Jones 1997; Chimchome et al., 1998). In the Pillur valley, Madhuca longifolia is the dominant nesting tree for the MPH. This tree species is a hardwood tree, but is susceptible to heart rot that enhances cavity formation.

However, nest-tree and nest cavity factors may be the most important primary factors influencing the nest habitat choice in hornbills (Kannan, 1994). Nests of the Malabar Grey Hornbill were found in open, tall, evergreen forest along forest trails, edges and interior areas. The data obtained reflect size and age of nest trees and indicate that hornbills prefer mature forest stands. Nesting site variables shows the maximum positively strong correlation between the nesting tree variables of the MPH. MPH's nest structural characteristics such as height of the tree, branch end, branch start and branch end distances height of the first branch, canopy length, nest holes availability and distance to human habitation were significant variables in the Pillur valley. Relatively more nests were found in trees of larger GBH classes, particularly in the $276-325$, and $>325 \mathrm{~cm}$ range. This cannot be taken to indicate the preference of the MPH, because it may simply reflect the higher availability of suitable cavities in larger trees. All eleven nests were in living trees. Mudappa \& Kannan (1997) found that a large DBH and greater height of lowest limb were significant parameters in the site assortment of the Malabar Grey Hornbill, though they chose smaller trees than the sympatric Great Hornbill in the Western Ghats (South India). Kannan (1994) found that structural characteristics (e.g. large size and maturity of forest around the nest trees) were important in nest site selection by the Great Hornbill in the Western Ghats, where thirteen tree species were used for nesting.

The nests of the Malabar Grey Hornbill were located at substantial heights in evergreen forest trees. The height at which the nest is located may simply reflect the fact that nest cavities are formed more frequently in the higher reaches of the tree. Kemp (1976) reported that the tendency of the hornbill to choose cavities with a small entrance has been observed in Africa. Several hornbills were seen assiduously enlarging the nest cavity entrance by removing overgrown wood tissue and debris. In this study, Kemp (1976) reported about the «funk-holes» type discovered for most hornbills in the African and Oriental regions. The estimation of cavities showed the availability of nest holes of 4.57 per $0.01 \mathrm{~km}^{2}$ $\left(0.025 \mathrm{~km}^{2}\right.$ total sample area), which is an inadequate sample. Mudappa \& Kannan (1997) recorded a relatively high density of ten cavities per 0.01 $\mathrm{km}^{2}$ for the Malabar Grey Hornbill in Annamalai areas of Western Ghats region. The MPH showed a slight preference for some nest site characteristics other than tree species. There were height and size of trees, and their commonness in the habitat. These trees were represented by durable hardwood ones. Poonswad (1993) noted that this is probably because of such trees last longer. And once cavities are formed, they can be used by hornbills for a long time, given the durability of the trees. 


\section{Conclusions}

The current study provides some baseline information of the MPH in the Pillur Valley, which will help to prepare a management plan for the MPH conservation. The tree Madhuca longifolia contains the highest number of MPH nests. This tree species has flowers, seeds and bark of highly medicinal value being used by tribal people for various diseases. Therefore, the utilisation of this tree species in the MPH nesting zones will need more protection. Most of the nesting trees are located nearer to human habitation and agricultural lands. The extension of agricultural activities in the riverine forests disturbs breeding sites. All hornbill nests were located in trees, which are tall, with a large girth and located in a riverine habitat. Therefore, we recommend the protection and conservation of nest trees and the entire lowland riverine habitats in the Pillur valley. Conducting systematic surveys to locate nests of the hornbills, regular monitoring and protection of the nest sites (trees) are necessary. We also recommend the creation of awareness among forest staff and local people. Further conducting of long-term studies on the breeding biology of the MPH in Pillur valley is required.

\section{References}

Ali S., Ripley S.D. 1987. Compact Handbook of the Birds of India and Pakistan together with those of Bangladesh, Nepal, Bhutan and Sri Lanka (2nd Edition, Vol. 1-10). Delhi: Oxford University Press. 890 p.

Bachan A.K.H. 2006. The Hornbill haven. Sanctuary Asia 25(6): 46-49.

Bachan K.H.A., Kannan R., Muraleedharan S., Kumar S. 2011. Participatory conservation and monitoring of Great Hornbills and Malabar Pied Hornbills with the involvement of endemic Kadar tribe in the Anamalai Hills of southern Western Ghats, India. The Raffles Bulletin of Zoology Suppl. 24: 37-43.

Balasubramanian P., Prasad S.N., Kandavel K. 1998. Role of birds in seed dispersal and natural regeneration of forest plants in Tamil Nadu. Technical Report No. 7. Coimbatore, India: Salim Ali Centre for Ornithology and Natural History. 33 p.

Balasubramanian P., Saravanan R., Maheshwaran B. 2004. Fruit preferences of Malabar Pied Hornbill Anthracoceros coronatus in Western Ghats, India. Bird Conservation International 14(S1): 69-79. DOI: 10.1017/S0959270905000249

Bennett E.L., Nyaoi A.J., Sompud J. 1997. Hornbills Buceros spp. and culture in Northern Borneo: can they continue to coexist? Biological Conservation 82(1): 41-46. DOI: 10.1016/S0006-3207(97)00012-8

Birdlife International. 2016. Anthracoceros coronatus. In: The IUCN Red List of Threatened Species 2016:e. T22682433A92945240. Available from http://dx.doi.org/10.2305/IUCN.UK.2016-3.RLTS. T22682433A92945240.en

Chimchome V., Vidhidharam A., Simchareon S., Bumrungsri S., Poonswad P. 1998. Comparative study of the breeding biol- ogy and ecology of two endangered hornbill species in Huai Kha Khaeng Wildlife sanctuary, Thailand. In: P. Poonswad (Ed.): The Asian hornbills: Ecology and Conservation. Bangkok. Thai Studies in Biodiversity. P. 111-136.

Cody M.L. 1985. An introduction to habitat selection in birds. In: M.L. Cody (Ed.): Habitat Selection in Birds. Orlando, Florida: Academic Press. P. 3-56.

Collar N.J., Crosby M.J., Stattersfield A.J. 1994. Birds to Watch 2: The World List of Threatened Birds (BirdLife Conservation Series No. 4): The Official Source for Birds on the IUCN Red List. Cambridge: BirdLife International (BirdLife Conservation Series 4). 407 p.

Conner R.N. 1976. Nesting habitat of Red-headed Woodpeckers in Southwestern Virginia. Bird Banding 471: 40-43.

Conway C.J., Martin T.E. 1993. Habitat suitability for Williamson's sapsuckers in mixed conifer forests. Journal of Wildlife Management 57(2): 322-328. DOI: 10.2307/3809429

Datta A. 1998. Hornbill abundance in unlogged forest, selectively logged forest and a forest plantation in Arunachal Pradesh, India. Oryx 32(4): 285-294. DOI: 10.1046/ j.1365-3008.1998.d01-58.x

Datta A., Rawat G.S. 2004. Nest-site selection and nesting success of three hornbill species in Arunachal Pradesh, northeast India: Great Hornbill (Buceros bicornis), Wreathed Hornbill (Aceros undulates), and Oriental Pied Hornbill (Anthracoceros Albirostris). Bird Conservation International 14(S1): 39-52. DOI: 10.1017/S0959270905000213

Gómez E.D. 2014. Effects of tree retention on cavity- nesting birds in northern Sweden University. M.Sc. Thesis. Umea: Sweden University of Agricultural Sciences. 35 p.

James E.C., Shugart Jr.H.H. 1970. A quantitative method of habitat description. Audubon Field Notes 241: 727-736.

Kalina J. 1988. Nest intruders, nest defense and foraging behavior in the Black-and-white Casqued Hornbill (Bycanistes subcylindricus). Ibis 131(4): 567-571. DOI: 10.1111/j.1474-919X.1989.tb04791.x

Kannan R. 1994. Ecology and conservation of the Great Pied Hornbill (Buceros bicornis) in the Western Ghats of southern India. PhD Thesis. USA: University of Arkansas. 157 p.

Kannan R., James D.A. 1997. Breeding Biology of the Great Pied Hornbill (Buceros bicornis) in the Anaimalai Hills of Southern India. Journal of Bombay Natural History Society 94: 451-465.

Kemp A.C. 1970. Some observations on the sealedin nesting method of hornbills (Family Bucerotidae). Ostrich 40(sup.8): 149-155. DOI: 10.1080/00306525.1969.9639117

Kemp A.C. 1976. A study of the ecology, behaviour and systematics of Tockus hornbills (Aves: Bucerotidae). Series Memoir (Transvaal Museum) No. 20. Pretoria: Transvaal Museum. 125 p.

Kemp A.C. 1995. The Hornbills: Bucerotiformes. Oxford: Oxford University Press. 302 p.

Kemp A.C., Kemp M.I. 1972. A study of the biology of the Monteiro's Hornbill. Annals of the Transvaal Museum 27(13): 255-268.

Kinnaird M.F. 1998. Evidence for effective seed dispersal by the Sulawesi Red-knobbed Hornbill Aceros cassidix. Biotropica 30(1): 50-55. DOI: 10.1111/j.1744-7429.1998.tb00368.x

Kinnaird M.F., O’Brien T.G. 1993. Preliminary observations on the breeding biology of the endemic Sulawesi Red- 
knobbed Hornbill (Rhyticeros cassidix). Tropical Biodiversity 30(1): 107-112.

Leighton M., Leighton D.R. 1983. Vertebrate responses to fruiting seasonality within a Bornean rainforest. In: S.L. Sutton, T.C. Whitmore, A.C. Chadwick (Eds.): Tropical Rainforests: Ecology and Management. Oxford: Blackwell Scientific. P. 181-209.

Li P., Martin T E. 1991. Nest-site selection and nesting success of cavity nesting birds in high elevation forest drainages. Auk 108(2): 405-418.

Mardiastuti A., Mulyani A., Rinaldi D., Puryanto. 1996. Nest site characteristics of Wreathed Hornbill Aceros undulatus in Meru Betiri National Park, East Java, Indonesia. In: Second International Asian Hornbill Workshop. Bangkok, Thailand.

Marsden S.J., Jones M.J. 1997. The nesting requirements of the parrots and hornbill of Sumba, Indonesia. Biological Conservation 82(3): 279-287. DOI: 10.1016/ S0006-3207(97)00038-4

Martin T.E. 1988. Processes organizing open-nesting bird assemblages: competition/nest predation? Evolutionary Ecology 2(1): 37-50. DOI: 10.1007/BF02071587

Mudappa D., Kannan R. 1997. Nest site characteristics and nesting success of Malabar Grey Hornbill in southern Western Ghats, India. Wilson Bulletien 109(1): 102-111.

Mudappa D., Raman T.R.S.F. 2009. A conservation status survey of hornbills (Bucerotidae) in the Western Ghats, India. Indian Bird 5(4): 90-102.

O’Brien T. G., Kinnaird M.F., Jepson P., Setiwan I. 1998. Effect of the forest size and structure on the distribution of
Sumba Wrethed Hornbills Aceros everetti. In: P. Poonswad (Ed.): The Asian Hornbills: Ecology and Conservation (Thai studies in Biodiversity No.2). P. 209-218.

Poonswad P. 1993. Comparative ecology of sympatric hornbills (Bucerotidae) in Thailand. PhD Thesis. Osaka: Osaka City University. 316 p.

Poonswad P., Tsuji A., Ngarmporgsai C. 1983. A study of the breeding biology of hornbills (Bucerotidae) in Thailand. In: Proceedings of the Jean Delacour/IFCB Symposium on breeding birds in captivity. North Hollywood: International Foundation for the Conservation of Birds. P. 239-265.

Raman T.R.S. 2001. Effect of Slash-and-Burn shifting cultivation onrainforest birds in Mizoram, Northeast India. Conservation Biology 15(3): 685-698. DOI: 10.1046/j.1523-1739.2001.015003685.x

Raman T.R.S., Mudappa D. 2003. Correlates of hornbill distribution and abundance in rainforest fragments in the Southern Western Ghats, India. Bird Conservation International 13(3): 199-212. DOI: 10.1017/S0959270903003162

Reddy M.S. 1988. Some aspects of ecology and behaviour of hornbills with special reference to Anthracoceros coronatus (Boddaert) from North Kanara district of Western Ghats. PhD Thesis. Dharwad: Karnataka University. 307 p.

Reddy M.S., Muralidhar K.S., Gandhi M., Basalingappa S. 1990. Distribution and variation in number of Malabar Pied Hornbills Anthracoceros coronatus (Boddaert) in selected areas of north Kanara forest of Western Ghats in Karnataka, India. The Indian Zoologist 14: 63-73.

\title{
ПРЕДПОЧТЕНИЯ ИНДИЙСКОЙ ПТИЦЫ-НОСОРОГА (ANTHRACOCEROS CORONATUS) В ВЫБОРЕ ДЕРЕВЬЕВ ДЛЯ ГНЕЗДОВАНИЯ В ДОЛИНЕ ПИЛУР, ЗАПАДНЫЕ ГАТЫ, ЮЖНАЯ ИНДИЯ
}

\author{
П. Гирикаран ${ }^{1}$, А. Самсон ${ }^{1, *}$, Б. Рамакришнан ${ }^{1}$, С. Рамасубраманиан ${ }^{2}$ \\ ${ }^{1}$ Правительственный колледж искусств, Индия \\ ${ }^{2}$ Лесной отдел штата Тамилнад, Индия \\ *e-mail:kingvulture1786@gmail.com
}

Индийская птица-носорог (Anthracoceros coronatus) является видом, близким к угрожаемому состоянию. Этот вид является эндемиком для низинных влажных лесов Западных Гат, нескольких участков в Центральной Индии, Восточных Гатах и Шри-Ланке. Целью настоящего исследования было изучение предпочтений A. coronatus в выборе деревьев для гнездования в долине Пилур в Западных Гатах (штат Тамилнад, Южная Индия) с ноября 2017 г. по март 2018 г. В результате было определено пять деревьев, выбираемых индийской птицей-носорогом для гнездования на территории исследования. Большинство из деревьев для гнездования относились к лиственным деревьям. Среди всех определенных нами видов деревьев Madhuca longifolia включала наибольше число гнезд (n = 6), а также была представлена наибольшим числом деревьев $(\mathrm{n}=5)$, выбранных для гнездования. Всего было рассчитано 17 показателей гнездовых участков, чтобы понять предпочтения индийской птицы-носорога в выборе дерева для гнездования. Изучение положения гнезд на каждом из деревьев, выбранных для гнездования $A$. coronatus, показало, что 55\% гнезд располагалось на ветвях первого порядка. Изучение положение гнезда по отношению к сторонам света на каждом дереве показало, что большинство гнезд $(\mathrm{n}=7)$ было расположено на северо-восточной стороне. Общая длина и ширина полости гнезда составили 31.38 см и 18.06 см соответственно. Форма полости гнезда показывает, что большинство из них (70\%) имеет овальную форму и 30\% гнезд наблюдались в виде круглой формы независимо от вида дерева, выбранного для гнездования. Потенциальная доступность дерева для гнездования и полости гнезда на территории исследования показывает, что для исследуемых участков, охватывающих площадь 0.025 км², общая доступность деревьев для гнездования GBH $\geq$ 250 см составила 9.43 на 0.01 км² (23.57 деревьев) и наличие гнезд составило 4.57 на 0.01 км², включая 13 видов.

Ключевые слова: вторичный дуплогнездник, дуплогнездник, Коимбатур, плодоядный, птица-носорог, Тамилнад 